\title{
Trait-mediated indirect interactions among residents of rocky shore tidepools
}

\author{
Steven G. Morgan ${ }^{1,2, *}$, Sarah A. Gravem ${ }^{1,3}$, Adam C. Lipus ${ }^{1}$, Marcos Grabiel ${ }^{1}$, \\ Benjamin G. Miner ${ }^{4}$
}

${ }^{1}$ Bodega Marine Laboratory, University of California-Davis, Bodega Bay, CA 94923, USA
${ }^{2}$ Environmental Science and Policy, University of California-Davis, Davis, CA 95616, USA
${ }^{3}$ Department of Integrative Biology, Oregon State University, Corvallis, OR 97331, USA
${ }^{4}$ Department of Biology, Western Washington University, Bellingham, WA 98225, USA

ABSTRACT: Trait-mediated indirect interactions (TMIIs) are an important component of food web structure and dynamics. We determined whether TMIIs occur in rocky tidepool communities on the west coast of the USA. In the laboratory, both adults and juveniles of the keystone predator Pisaster ochraceus and adults of a smaller predatory seastar Leptasterias spp. caused the abundant herbivorous snail Tegula funebralis to stop foraging and flee the water, inducing a positive TMII on micro- and macroalgae. Snails preferred 3 common species of macroalgae (Ulva lactuca, Cladophora columbiana and Porphyra spp.) over 4 others, indicating that seastars might provide the strongest benefits to these species in tidepools. In the laboratory, snails responded rapidly to both species of predatory seastars and many more snails responded than could be eaten; thus, there is a potential for TMIIs to occur in natural populations. Snails responded to waterborne cues from $P$. ochraceus by reducing grazing and leaving still water, and reducing grazing in laminar flow $\left(0.51 \mathrm{~min}^{-1}\right)$, resulting in TMII effects at least as far as $75 \mathrm{~cm}$ away. Adult $P$. ochraceus and Leptasterias spp. introduced to tidepools during low tide induced many snails to flee the tidepools. Considerable individual variation occurred in the responses of snails. Medium and large snails mediated TMIIs and hungry snails were marginally less responsive to seastars potentially altering TMII strength in nature. Thus, we demonstrated that TMIIs could occur in natural tidepools and showed how predator and algal identity, predator and prey size, water flow and prey hunger level may influence these TMIIs.

KEY WORDS: Trait-mediated indirect interaction · Predator-prey interaction · Chemical cue Community structure $\cdot$ Rocky intertidal tidepools $\cdot$ Nonconsumptive effect

\section{INTRODUCTION}

The concept of trophic cascades has undergone substantial expansion in recent years. Originally, predators were shown to decrease populations of herbivores thereby indirectly increasing populations of primary producers (Hairston et al. 1960, Paine 1980), which was known as density-mediated indirect interactions (DMII; Abrams 1995, 2007, Peacor \& Werner 1997). In recent decades, investigators have

${ }^{*}$ Corresponding author: sgmorgan@ucdavis.edu discovered that predators can cause phenotypically plastic behavioral, morphological, physiological or life history trait changes in prey species, indirectly increasing populations of primary producers - a type of trait-mediated indirect interaction (TMII; Abrams 1995, 2007, Peacor \& Werner 1997). Indeed, TMII might be largely responsible for the indirect effects observed in trophic cascades (Peacor \& Werner 2001, Preisser et al. 2005, Trussell et al. 2006, Peckarsky et al. 2008).

(C) The authors 2016. Open Access under Creative Commons by Attribution Licence. Use, distribution and reproduction are unrestricted. Authors and original publication must be credited. 
More recently, investigators have begun focusing on the context-dependency of TMII and factors altering its strength, such as environmental variation, features of informational cues, timing of measurements and individual variation in the traits of mediating species (Luttbeg et al. 2003, Luttbeg \& Trussell 2013, Matassa \& Trussell 2014, Weissburg et al. 2014, Gravem \& Morgan 2016). For example, the transmission of predator cues to prey is strongly influenced by the environment, and air and water flow are particularly important for chemosensory cues (Smee et al. 2010, Weissburg et al. 2014). Prey may respond differently depending on predator size or identity, which can influence TMII strength (Peckarsky \& McIntosh 1998, Bernot \& Turner 2001, Weissburg et al. 2014). Predators will be more likely to benefit some primary producers more than others because prey species usually exhibit preferences for particular forage species (Schmitz 1998). Individual variation in prey species is particularly relevant for behaviorally mediated TMII because the foraging and the antipredator behavior of prey individuals depends on their traits, including size, hunger and temperament (Werner \& Anholt 1993, Lima 1998a, Sih et al. 2004). There is mounting evidence that these statedependent decisions by prey can alter the strength of TMII (Sih 1992, Freeman 2006). For example, hungry prey individuals are often less responsive to predators, and therefore mediate weaker TMIIs (Heithaus et al. 2007, Matassa \& Trussell 2014, Gravem \& Morgan 2016). Large individuals also might have different antipredator behaviors, vulnerabilities, energetic demands and feeding rates than smaller prey individuals, which might subsequently affect the strength of TMII (Luttbeg et al. 2003, Persson \& De Roos 2003, Freeman 2006, Gravem \& Morgan 2016). Thus, individual variation in prey state likely alters the strength of TMII, but empirical tests are necessary to identify when individual variation is important, and whether such individual variation has community-level consequences.

Many TMIIs have been demonstrated in freshwater communities (Peacor \& Werner 2001, Preisser et al. 2005, Trussell et al. 2006), perhaps due to the ease of chemoreception of waterborne cues from predators-the main sensory modality in aquatic invertebrates (Preisser et al. 2005, Selden et al. 2009, Long \& Hay 2012). The fewer marine examples of TMII (Dill et al. 2003, Long \& Hay 2012) are generally from the laboratory (Appleton \& Palmer 1988, Behrens Yamada et al. 1998, Aschaffenburg 2008, Quinn et al. 2012) or from wave-protected marine environments such as estuaries (but see Rai- mondi et al. 2000, Trussell et al. 2004, Heithaus et al. 2007, Wada et al. 2013, Matassa \& Trussell 2014). The underrepresentation of examples from opencoast marine environments might be because strong turbulence and advection dilute cues, render chemical cues less detectable and diminish the importance of TMII (Weissburg \& Zimmer-Faust 1993, Weissburg et al. 2002, Large et al. 2011). Alternatively, such underrepresentation might simply stem from the logistical challenges of working in these environments during high tide, when cues are being transmitted and most behaviors are observable. To understand the importance of TMII in open-coast ecosystems, a logical first step is to test their importance in calm, isolated tidepools during low tide while chemical cues from predators are being transmitted (e.g. Trussell et al. 2004, Gravem \& Morgan 2016) before conducting experiments during high tides when waves and currents rapidly mix and advect cues (e.g. Matassa \& Trussell 2014). Tidepools also offer an advantage over other marine systems because replicate communities can be manipulated, and habitat shifts out of tidepools can be clearly defined (Trussell et al. 2002, 2004).

We investigated the potential for contextdependency of TMII in tidepool communities on rocky shores of the west coast of the USA. In this system, the original keystone predator, Pisaster ochraceus, and a much smaller predatory seastar, Leptasterias spp. (likely a species complex including $L$. hexactis and L. aequalis; see Flowers \& Foltz 2001, Carlton 2007 for details) prey on the abundant herbivorous snail Tegula funebralis (Yarnall 1964, Paine 1969), which in turn grazes micro- and macroalgae, and affects algal biomass and community structure (Nielsen 2001). We began the investigation by determining the feeding preferences of T. funebralis on 7 species of common macroalgae, to explore which species might be most strongly influenced by TMII and to choose the most palatable species for use in feeding trials with seastar predators. We then investigated the context-dependency of TMII in laboratory and field experiments to determine whether (1) predator identity and life stage, (2) responses by prey to waterborne predator cues in flowing and still water, (3) prey hunger level or (4) prey body size altered prey responses to predators (grazing and escape behaviors), and ultimately the strength of TMII on algae. We hypothesized that both seastar species would generate positive TMII, but adult $P$. ochraceus would have a more pronounced effect than Leptasterias spp. on $T$. funebralis behavior and indirect effects on algae, given that it is larger, faster and 
likely poses a bigger threat. We also compared similar-sized juvenile P. ochraceus and Leptasterias spp., expecting that Leptasterias spp. would have stronger effects on snail behavior and algae because it is a more effective predator on mobile prey (Menge 1972). Furthermore, we expected that predators farther from prey in the flow would elicit weaker antipredator responses and TMII as the cues became increasingly diluted. We also expected smaller snails to exhibit stronger responses and mediate stronger TMII than larger snails in the presence of Leptasterias spp. because Leptasterias spp. is unable to consume large snails (Gravem \& Morgan 2016). Conversely, we expected all sizes of snails to respond to and mediate TMII in the presence of juvenile $P$. ochraceus, since all sizes of snails are vulnerable to adult $P$. ochraceus and snails might not be able to distinguish $P$. ochraceus size based on chemical cues (Selden et al. 2009). Finally, we expected that snail responses and TMIIs would be stronger when snails were sated rather than hungry because they would be more inclined to suspend feeding when seastars were present (Werner \& Anholt 1993, Clark 1994). Thus, this suite of experiments was intended to reveal whether TMIIs are likely to occur in nature, and if so, the processes driving them in tidepool communities on the west coast.

\section{MATERIALS AND METHODS}

\section{Collections}

All experiments were conducted during the spring and summer of 2004 to 2014. We collected Tegula funebralis, Leptasterias spp., Pisaster ochraceus and all macroalgae except Ulva lactuca from Horseshoe Cove, adjacent to the Bodega Marine Laboratory in northern California, USA $\left(38.36^{\circ} \mathrm{N}, 123.1^{\circ} \mathrm{W}\right)$. We collected sheets of $U$. lactuca from nearby Bodega Harbor for ease of collection, but it also occurs in Horseshoe Cove. We grew the microalgae for TMII experiments in outdoor flow-through seawater tables for at least $3 \mathrm{~d}$ until it evenly covered the tiles or plates used in the trials. We kept newly collected snails and seastars in flow-through seawater tables in the laboratory for $24 \mathrm{~h}$ without food before experiments to standardize hunger levels and to acclimate animals to laboratory conditions. The one exception was for experiments examining the effect of hunger level of snails in response to seastars, whereby snails were starved or fed in the laboratory for $1 \mathrm{wk}$ before the experiments began. We measured snails across the widest diameter of shells, Leptasterias spp. across the widest diameter from the tips of opposing rays and $P$. ochraceus from the madreporite to the tip of the ray.

\section{Palatability of macroalgae}

We determined the most palatable species of macroalgae to use in 12 replicate feeding trials by giving separate T. funebralis (mean diameter: $14.5 \pm 0.6 \mathrm{~mm}$ SE) a choice of a piece of algae of a standardized size $\left(\sim 2.5 \mathrm{~mm}^{2}\right)$ from 7 species of macroalgae in covered culture dishes $(9 \mathrm{~cm}$ diameter $\times 5 \mathrm{~cm}$ tall). Algal species were Cladophora columbiana, Fucus gardneri, Endocladia muricata, Mastocarpus papillatus, Pelvetiopsis limitata, Porphyra spp. and Ulva lactuca. Dishes were filled with seawater and bathed in flowing seawater in the laboratory. We changed the seawater and cleaned the dishes twice daily to eliminate any microalgae, and we estimated the percentage of algae eaten compared to the original standard size 11 times over $12 \mathrm{~d}$. Because we measured the percentage of algae eaten on the same pieces of algae over time, we conducted repeated measures analysis of variance (ANOVA) followed by Tukey's HSD test to examine the effect of algal species on the arcsine square root transformed proportion of algae eaten. Because U. lactuca was the most preferred alga, it was used in subsequent TMII experiments (see Fig. 1).

\section{TMII laboratory experiments}

\section{Experimental design and analysis}

The basic design of the TMII experiments in the laboratory was a factorial design of seastar presence and absence crossed with snail presence and absence. In all treatments, we placed microalgae that was covering 1 microscope slide $(7.6 \times 2.6 \mathrm{~cm})$ or 2 porcelain tiles $(2.54 \times 2.54 \mathrm{~cm})$, or $U$. lactuca $(\sim 1 \mathrm{~g}$ wet weight) in a covered mesocosm half filled with seawater. In 'snail present' treatments, we placed $1 \mathrm{~T}$. funebralis in each mesocosm. In 'seastar present' treatments, we added 1 predatory Leptasterias spp. or P. ochraceus per mesocosm to test for the effects of seastar presence on snail behavior and TMII. Treatments with a snail but no seastar served as a control for snail behavior without seastars. Treatments without a snail or seastar served as a control for the clearing of algae by micrograzers. 
Treatments without a snail but with a seastar served as a control for disturbance of algae by the predator. We recorded whether snails were out of the water every $5 \mathrm{~min}$ for $1 \mathrm{~h}$. Grazing was quantified by measuring the cover of microalgae removed using a gridded quadrat $(1 \times 1 \mathrm{~cm}$ grid) made of transparent plastic film (the cover on the 2 tiles were averaged when present) or weight loss of U. lactuca after blotting it dry with tissue paper. For all TMII experiments detailed below (experiments with Leptasterias spp., juvenile and adult $P$. ochraceus, and waterborne cues in still water), we analyzed the main and interactive effects of the presence of the snail and seastar on the percentage of algae grazed using a 2-factor ANOVA. Analyses of the presence of seastars on the percent time snails spent out of water or analyses that did not include the snailabsent controls were analyzed by 1 -factor ANOVA. Algae did not change in any of the treatments without snails. Proportions were arcsine square root transformed so they were normally distributed and homoscedastic, except where noted.

\section{Seastar species and life stage}

Though the design was the same, methodological details differed between trials with adult $P$. ochraceus and those with juvenile $P$. ochraceus and Leptasterias spp. For Leptasterias spp. (mean diameter: $20.0 \pm$ $0.05 \mathrm{~mm} \mathrm{SE}$ ) and juvenile $P$. ochraceus (mean arm length: $33.2 \pm 6.2 \mathrm{~mm}$ ), we used small culture dishes (11 cm diameter $\times 8 \mathrm{~cm}$ depth) as our mesocosms. We did not cage seastars because they did not eat snails (11.4 to $21.4 \mathrm{~mm}$ diameter), which were similar in size to the seastars. The seastars were selected to be similar in size to each other to keep the chemical cue concentrations and encounter rates with snails similar between seastar species. To determine the effect of Leptasterias spp. on grazing by snails, the number of replicate mesocosms per treatment were 143 for seastar and snail, 141 for snail only, 78 for seastar only and 73 for neither seastar nor snail. We also recorded the percent time spent out of water for 128 of the mesocosms for the seastar and snail treatment, 126 mesocosms for the snail only treatment and all of the seastar only and neither seastar nor snail treatments. For juvenile $P$. ochraceus, we conducted 69 replicate mesocosms with a seastar and snail, 63 replicates with a snail only, 12 replicates with a seastar only and 12 replicates with neither seastar nor snail. For adult $P$. ochraceus $(6$ to $8 \mathrm{~cm}$ arm length), we used large, clear plastic bins as our meso- cosms $(40 \times 25 \times 10 \mathrm{~cm})$ to accommodate their larger size. We added 50 snails to each of 14 replicate mesocosms for the 2 snail treatments. We caged the seastars in plastic mesh pouches to prevent them from eating snails. We conducted 3 replicate mesocosms for controls without seastars or snails, but we did not add a second control with an empty pouch.

We provided only microalgae to snails in experiments with Leptasterias spp. and juvenile $P$. ochraceus. We provided microalgae or U. lactuca $(\sim 1 \mathrm{~g}$ wet weight) to snails in experiments with adult $P$. ochraceus to determine if food type affected the TMII. Experiments with Leptasterias spp. and juvenile $P$. ochraceus were conducted for $1 \mathrm{~h}$ while recording whether snails were out of the water every 5 min, and experiments with adult $P$. ochraceus were conducted for $8 \mathrm{~h}$ (approximate length of a low tide in the upper intertidal) with mesocosms partially submerged in flowing seawater to maintain ambient temperatures during these longer trials. The number of snails grazing rather than the percent time out of water was recorded at the end of the experiment and analyzed by ANOVA following arcsine square root transformation.

\section{Individual variation}

During the many replicate trials with Leptasterias spp. and juvenile $P$. ochraceus, we were struck by the large degree of variation in the responses of snails to seastars and the corresponding effects on algae. To investigate the source of this variation, we specifically examined the effect of snail size (small: $\leq 13 \mathrm{~mm}$ diameter; large: 14 to $40 \mathrm{~mm}$ ) for both seastar species, and hunger (starved or not starved for $24 \mathrm{~h}$ ) for Leptasterias spp. Unexpectedly, neither size nor hunger affected grazing or time spent out of water by snails (see the Supplement at www.int-res.com/ articles/suppl/m552p031_supp.pdf). Consequently, we repeated size experiments with Leptasterias spp. by including more replicates and 3 size classes: small ( 6 to $12 \mathrm{~mm}$ ), medium (12 to $18 \mathrm{~mm}$ ) and large (18 to $25 \mathrm{~mm}$ ), using snails that were collected $1 \mathrm{~d}$ before trials. The starvation period was increased in hunger experiments using snails that were collected $1 \mathrm{wk}$ before trials, and were starved or allowed to graze on microalgae that had been growing naturally in tanks for $\sim 2 \mathrm{wk}$. We used 2 unglazed porcelain tiles $(2.54 \times$ $2.54 \mathrm{~cm}$ ) covered with microalgae and medium to large Leptasterias spp. (2 to $5 \mathrm{~cm}$ diameter with size randomized) in both experiments and only mediumsized snails in hunger experiments. Individual snails 
were used only once in the experiments. For size experiments, we conducted 26 replicate mesocosms for all treatment combinations (size $\times$ seastar treatment), except the 2 control treatments without snails for which there were 9 replicate mesocosms each. For hunger experiments, we conducted 52 replicate mesocosms for the 2 treatments with seastars and 51 replicate mesocosms for the 2 treatments without seastars, except there were only 12 replicate mesocosms each for the 2 control treatments without snails. To obtain this many replicates, we conducted the size experiments on 3 different dates and the hunger experiments on 4 different dates, with treatments evenly distributed among dates.

We analyzed the main and interactive effects of seastar and snail treatment on the proportion of time spent out of water, proportion of time spent grazing, and proportion of algae grazed using ANOVA for size experiments and restricted maximum likelihood (REML) mixed models for hunger experiments. For analyses of hunger experiments, date was included as a random variable to test for differences among the trials due to varying conditions, such as water temperature and time of year. There were not enough degrees of freedom available to include date when analyzing size experiments, but very similar patterns occurred among all dates. All response variables were arcsine square root transformed to meet statistical assumptions of normality and equal variances.

\section{Waterborne cues}

We tested whether waterborne cues initiate TMIIs by substituting water saturated with the scent of adult $P$. ochraceus for the seastar itself in the same basic design as described above. We soaked several adult $P$. ochraceus (8 to $12 \mathrm{~cm}$ arm length) in seawater in aquaria (38 l) for several hours. We conducted 9 replicate mesocosms of the 2 treatments with snails and with or without seastar cues, and 3 replicate mesocosms of the 2 controls without snails. Data were analyzed similarly as described above, but using a Poisson general linear model (Wald chi-squared statistic) because data transformations did not result in normality or homogeneity of variance.

We used a different experimental design to test whether waterborne cues from adult $P$. ochraceus initiated TMIIs in flow and whether the effect diminished with increasing distance from the seastar. We partitioned plastic raceways $(31 \times 148 \times 25 \mathrm{~cm}$ deep $)$ with unidirectional flow $\left(7.6 \mathrm{~cm} \mathrm{~s}^{-1}\right)$ into 5 compartments (15 cm wide) using perforated plastic dividers (4 mm diameter holes). The first compartment was either empty ( $\mathrm{n}=6$ trials) or contained 1 adult $P$. ochraceus ( $\mathrm{n}=8$ trials). The 4 downstream compartments were located $0-15,15-30,60-75$ and $120-135 \mathrm{~cm}$ from the first compartment. We added $U$. lactuca (68 to $110 \mathrm{mg}$ ) and a clear acrylic disc (3 mm thick, $124 \mathrm{~mm}$ diameter) covered with microalgae to each compartment. We then placed $5 \mathrm{~T}$. funebralis (mean $14.5 \pm 0.62 \mathrm{~mm} \mathrm{SE}$ ) into each of 3 of the 4 compartments $(0-15,60-75$ and $120-135 \mathrm{~cm})$ and allowed them to graze for $16 \mathrm{~h}$; the 15 to $30 \mathrm{~cm}$ compartment served as a control for algal growth or grazing by microinvertebrates ( $\mathrm{n}=14$ total). We quantified grazing of microalgae and U. lactuca as previously described, except $U$. lactuca was spun in a salad spinner before blotting with tissue paper and weighing it. We analyzed the effects of the presence of $P$. ochraceus and distance from seastar on the mass of $U$. lactuca and proportion of microalgae grazed using a REML mixed model in a split-plot design followed by Tukey's test with the presence and absence of seastars and distance from $P$. ochraceus as main effects and trial as a random effect.

\section{TMII field experiments}

We investigated the potential for $P$. ochraceus and Leptasterias spp. to alter snail behavior and initiate TMIIs on tidepool algae in the field by performing brief experiments designed to be similar to our laboratory experiments. We began by surveying small shallow tidepools without seastars in the mid to high intertidal zone ( 0.15 to $1.0 \mathrm{~m}$ diameter and 1.25 to $2.25 \mathrm{~m}$ above mean lower low water [MLLW]). In each tidepool, we counted $T$. funebralis in the water and outside each tidepool in a 'halo' encompassing emersed rock $<15 \mathrm{~cm}$ around the perimeter, which likely serves as a refuge from predation during low tide (Menge \& Menge 1974). During experiments with Leptasterias spp., we added 1 Plexiglas plate $(12.7 \mathrm{~cm}$ diameter) to all tidepools at the beginning of low tide and added 2 seastars in mesh pouches to half of the tidepools. In experiments with $P$. ochraceus, we added a piece of $U$. lactuca comparable in size to the plates to all tidepools and 1 adult seastar in a mesh pouch to half of the tidepools. The pouches allowed the emission of chemical cues, while preventing predation or contact with snails. We resurveyed snails inside and outside tidepools and quantified the proportion of algae grazed using a gridded 
quadrat $\sim 5$ h later, before flood tide. For Leptasterias spp., we recorded the proportion of snails out of water in 23 replicate tidepools at the end of experiments with seastars and 17 replicate tidepools without seastars, and we recorded the proportion of microalgae grazed in 8 tidepools per treatment. For $P$. ochraceus, we recorded the proportion of snails out of water in 27 replicate tidepools with seastars and 14 replicate tidepools without seastars, and we recorded the proportion of snails grazing $U$. lactuca in 15 and 11 of the tidepools, respectively. For each species, we conducted 1-way ANOVAs to determine the effects of seastar presence on the arcsine square root transformed proportion of algae grazed by snails and the proportion of snails out of water.

\section{RESULTS}

\section{Palatability of macroalgae}

In descending order, snails ate more Ulva lactuca, Cladophora columbiana and Porphyra spp., followed by similar amounts of Pelvetiopsis limitata and Fucus gardneri and lastly similar amounts of Endocladia muricata and Mastocarpus papillatus (algae treatment: $F_{6,910}=172.0, \mathrm{p}<0.001$; time treatment: $F_{1,910}=$ 596.4, $\mathrm{p}<0.001$; algae $\times$ time: $F_{6,910}=2.9, \mathrm{p}=0.008$; Fig. 1). Based on this feeding trial, we used U. lactuca in experiments testing whether Pisaster ochraceus exert TMIIs on macroalgae in the laboratory and field.

\section{TMII laboratory experiments}

Seastar species and life stage

During encounters between Tegula funebralis and both species of seastars, snails immediately twisted their bodies and fled in the opposite direction, outpacing and escaping seastars. Snails left the water even when they did not touch the seastars, indicating that they were likely responding to dissolved chemical cues. Both Leptasterias spp. (snail treatment: $F_{1,401}=195.1, \mathrm{p}<0.001$; seastar treatment: $F_{1,401}=$ $37.6, \mathrm{p}<0.001$; snail $\times$ seastar: $F_{1,401}=43.2, \mathrm{p}<0.001$ ) and juvenile $P$. ochraceus (snail treatment: $F_{1,152}=$ 52.3, $\mathrm{p}<0.001$; seastar treatment: $F_{1,152}=8.5 \mathrm{p}=$ 0.004; snail $\times$ seastar: $\left.F_{1,152}=8.5, \mathrm{p}=0.004\right)$ exerted positive TMIIs on algae in the laboratory, decreasing grazing on microalgae by 3.1 and 2.6 times when snails were present, respectively (Fig. 2). On average, $T$. funebralis spent 4.2 fold more time out of water when Leptasterias spp. were present than absent $\left(t_{154}=32.49, \mathrm{p}<0.001\right.$; Fig. 2$)$ and 5.1 fold more time out of the water when $P$. ochraceus were present than absent $\left(t_{100}=70.09, \mathrm{p}<0.001\right)$.

Adult $P$. ochraceus initiated TMIIs on U. lactuca: $P$. ochraceus reduced the number of snails grazing by 9.0 fold compared to when they were absent $\left(t_{11}=\right.$ $4.29, \mathrm{p}=0.002$; Fig. 3), resulting in 8.4 times less algae grazed $\left(F_{26}=11.76, \mathrm{p}<0.001 ;\right.$ Fig. 3$)$. The difference in mass of algae was negligible when snails were absent (mean \pm SE change: $0.008 \pm 0.006 \mathrm{~g}$ ), indicating the effects of handling and other grazers were minimal, and measurement error was slight.

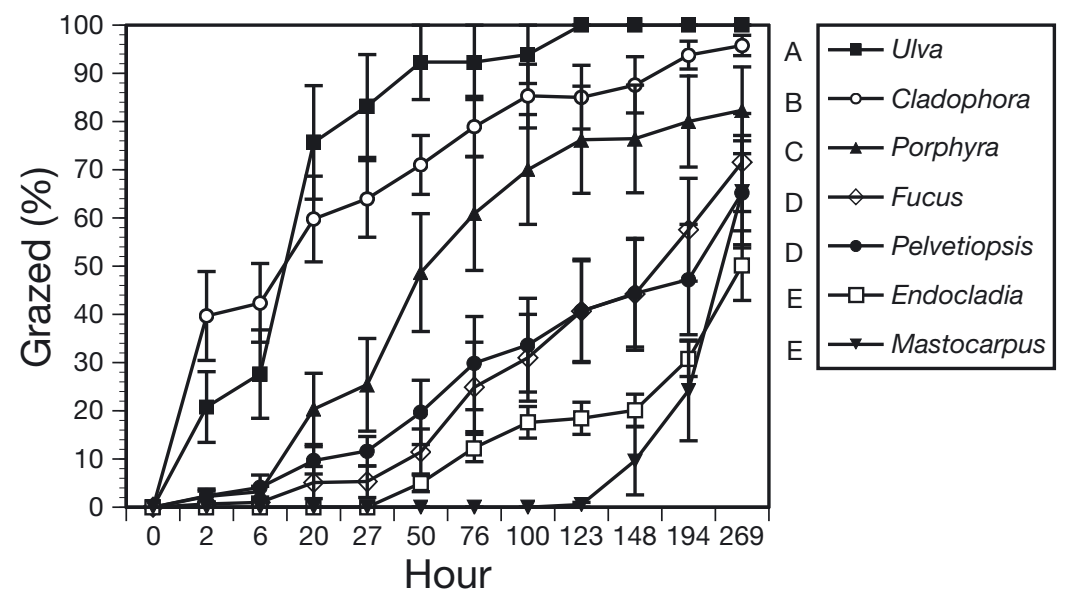

Fig. 1. Palatability of macroalgae. Cumulative mean $( \pm 1 \mathrm{SE})$ percent consumption of 7 taxa of macroalgae (Ulva lactuca, Cladophora columbiana, Porphyra spp., Pelvetiopsis limitata, Fucus gardneri, Endocladia muricata and Mastocarpus papillatus) by Tegula funebralis for $269 \mathrm{~h}$ during $12 \mathrm{rep}-$ licate trials for each species. Different letters indicate significant differences $(\mathrm{p}<0.001)$
Individual variation

Although Leptasterias spp. and juvenile $P$. ochraceus generally caused snails to forage less and flee the water more during TMII experiments in the laboratory, there was considerable individual variation among snails (Fig. 4). When Leptasterias spp. was absent, $71 \%$ of snails spent $<10 \%$ of time out of water for the duration of the experiment. The impact on microalgae was highly variable in the absence of Leptasterias spp., with $21 \%$ of snails grazing nearly all microalgae $(>90 \%)$ and $19 \%$ of snails grazing little microalgae $(<10 \%)$. A similar dichotomy in behavior occurred when juvenile $P$. ochraceus was absent, 

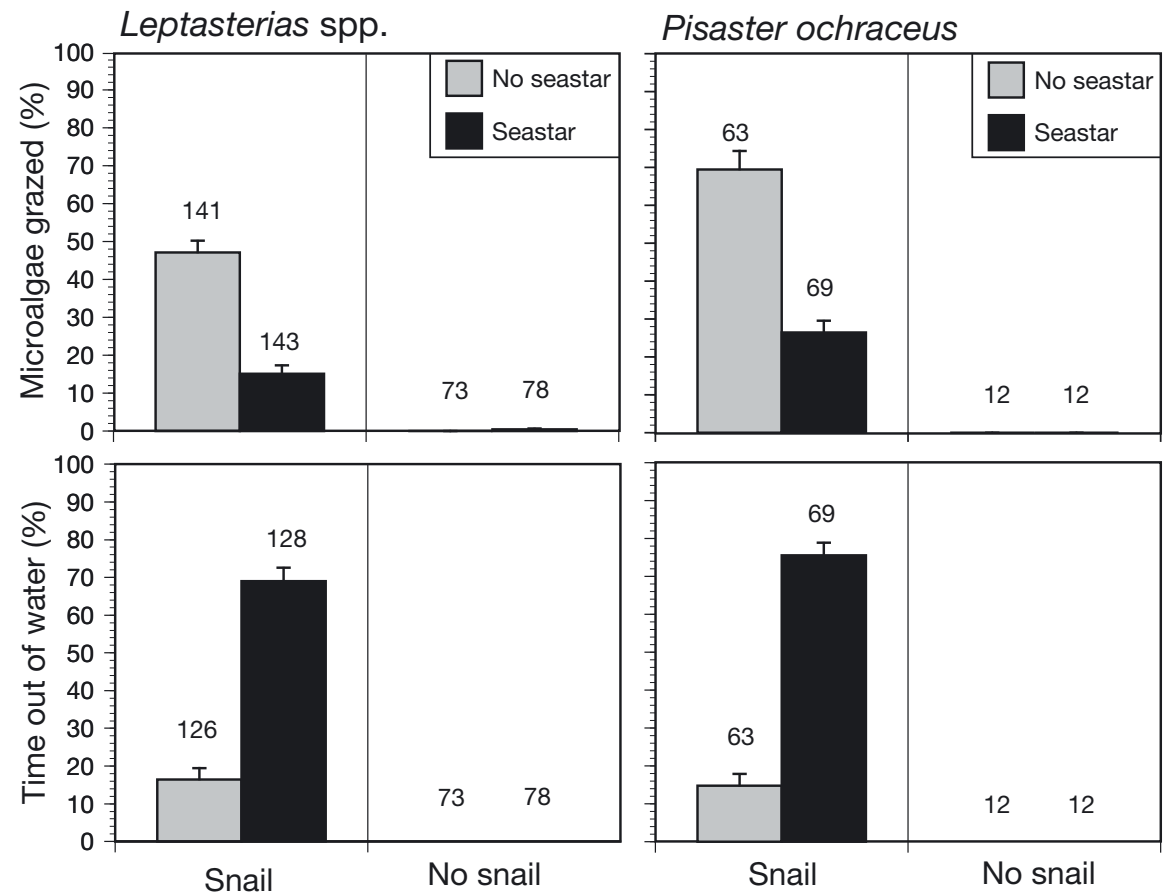

Fig. 2. Mean ( $\pm 1 \mathrm{SE}$ ) proportion of microalgae grazed (top) and proportion of time herbivorous Tegula funebralis spent out of the water (bottom) in the presence and absence of predatory Leptasterias spp. (left) and juvenile Pisaster ochraceus (right) after $1 \mathrm{~h}$ in the laboratory. Numbers of replicate mesocosms per treatment are shown

with $63 \%$ of snails spending $<10 \%$ of time out of the water. The tendency to either eat most of the microalgae or leave it nearly uneaten was even more pronounced in the absence of juvenile $P$. ochraceus, with $57 \%$ of snails grazing the microalgae nearly entirely $(>90 \%)$ and $17 \%$ of snails leaving the algae nearly uneaten $(<10 \%)$.

By contrast, when Leptasterias spp. was present, $41 \%$ of snails spent $>90 \%$ of the time out of water, and $63 \%$ of snails hardly ate any microalgae $(<10 \%)$. Similarly, when juvenile $P$. ochraceus was present,
$45 \%$ of snails spent $>90 \%$ of the time out of water, and $48 \%$ of snails ate hardly any microalgae $(<10 \%)$.

Small, medium and large snails responded similarly to Leptasterias spp. by spending 3.7, 3.7 and 2.3 times more time out of the water, respectively, than when seastars were absent (seastar treatment: $F_{1,150}=154.31, \mathrm{p}<0.001$; size: $F_{2,150}=1.25, \mathrm{p}=0.290$; seastar $\times$ size: $F_{2,150}=1.69, \mathrm{p}=0.188$; Fig. $5 \mathrm{a}$ ). Seastars also reduced grazing frequency by snails of all sizes $(12.9,8.3$ and 4.8 fold decreases in time spent grazing for small, medium and large snails, respec-

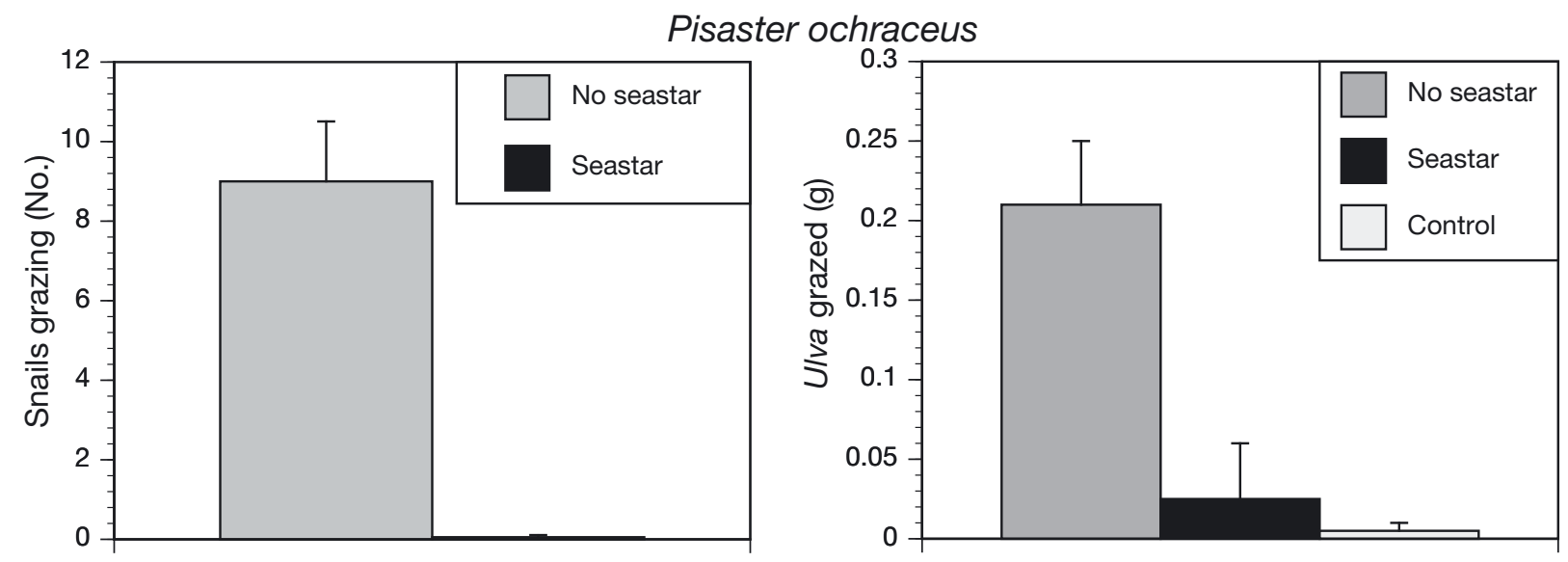

Fig. 3. Mean ( $\pm 1 \mathrm{SE}$ ) number of Tegula funebralis grazing (left) and decrease in wet mass of Ulva lactuca after $8 \mathrm{~h}$ in the presence and absence of adult Pisaster ochraceus in the laboratory (right); $\mathrm{n}=14$ replicate mesocosms per treatment (except $\mathrm{n}=3$ for controls without snails or seastars) 
No Leptasterias spp.
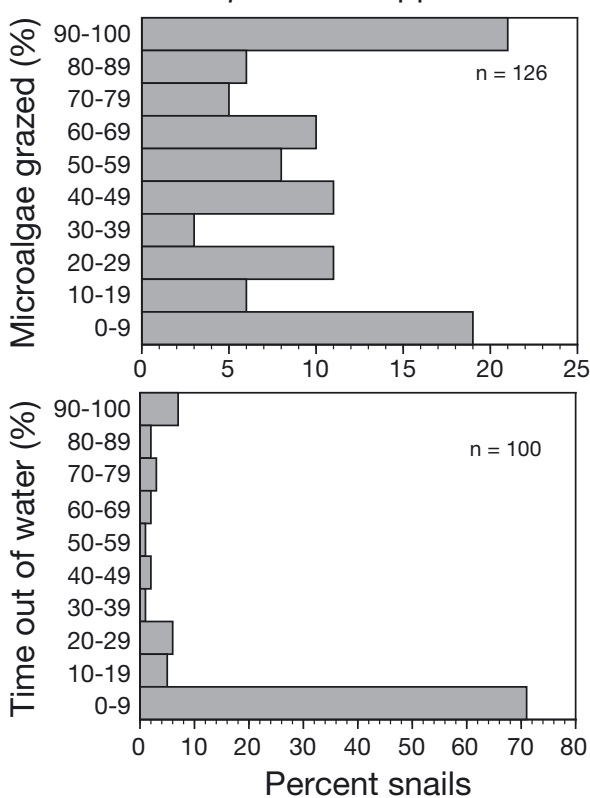

No Pisaster ochraceus
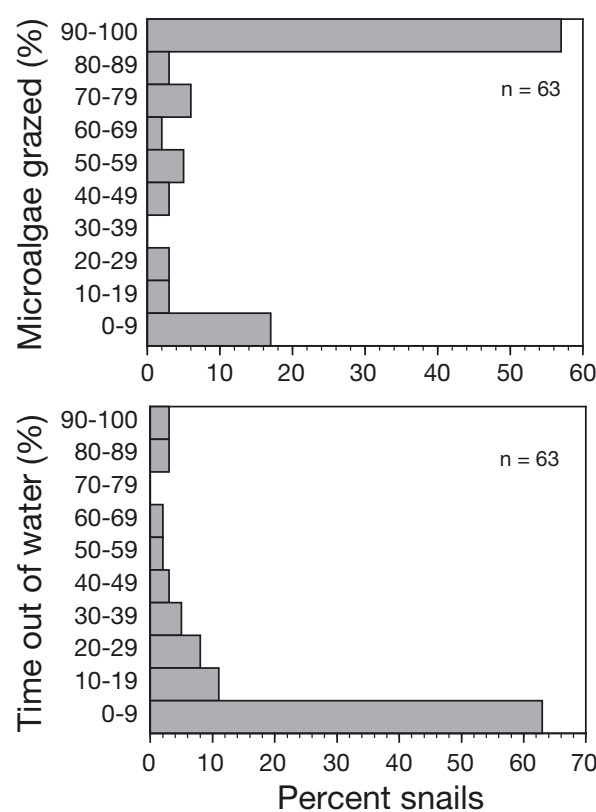

Fig. 4. Individual variation in microalgae grazed and time spent out of the water by Tegula funebralis (\%) in the presence and absence of Leptasterias spp. and juvenile Pisaster ochraceus during $1 \mathrm{~h}$ feeding trials in the laboratory. Number of replicate mesocosms per treatment are shown
Leptasterias spp.
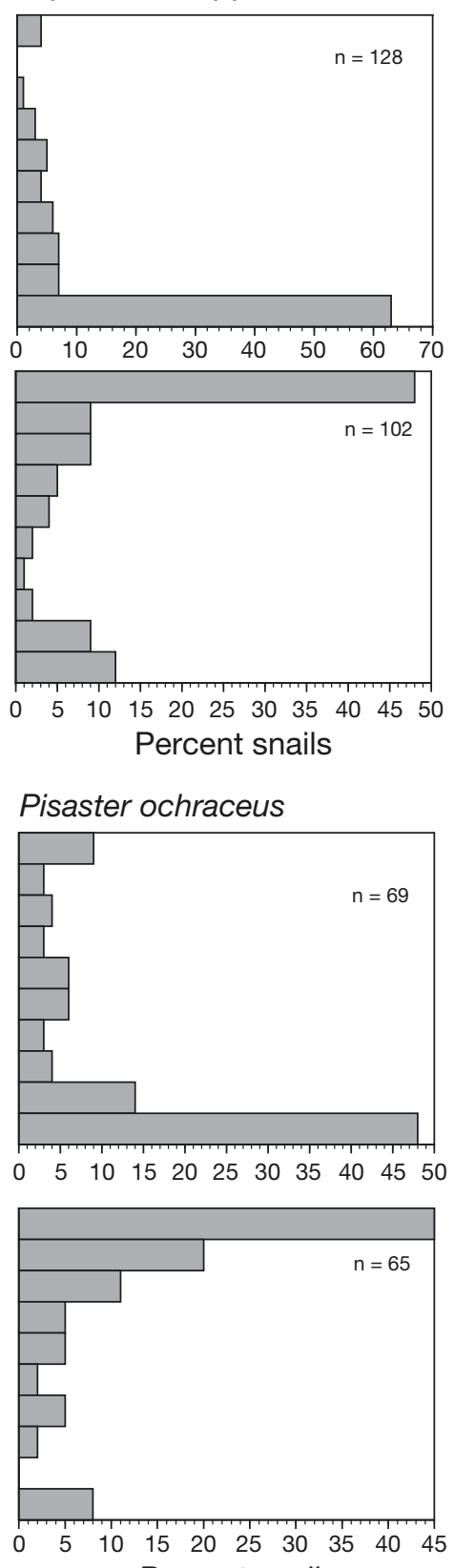

Percent snails tively; seastar treatment: $F_{1,150}=112.91, \mathrm{p}<0.001$; size: $F_{2,150}=1.34, \mathrm{p}=0.265$; seastar $\times$ size: $F_{2,150}=$ 1.89, $\mathrm{p}=0.155$; Fig. 5b). Contrary to expectations, only medium and large snails mediated positive TMIIs on algae (4.9 and 4.3 fold decreases in algae grazed, respectively) when seastars were present (seastar treatment: $F_{1,165}=83.21, \mathrm{p}<0.001$; seastar $\times$ size: $F_{3,165}=8.24, \mathrm{p}<0.001 ;$ Fig. $5 \mathrm{c}$ ). Small snails, though responsive to seastars, did not mediate a detectable TMII (3.4 fold decrease in algae grazed with seastars present), because they grazed much less algae overall than medium and large snails (size: $F_{3,165}=24.39, p<0.001$; Fig. $5 \mathrm{c}$ ).

Hungry snails spent more time in the water overall (hunger: $F_{1,198}=8.14, \mathrm{p}=$ 0.005; Fig. 5d), and fed and hungry snails responded similarly to Leptasterias spp. by spending 3.6 and 4.2 fold more time out of the water, respectively (seastar treatment: $F_{1,198}=137.94, \mathrm{p}<0.001$; seastar $\times$ hunger: $F_{1,198}=0.22, \mathrm{p}=0.640$; Fig. 5d). As expected, hungry snails grazed more often than fed snails overall (hunger: $F_{1,198}=60.88, \mathrm{p}<0.001$; Fig 5e). While both types of snails grazed less often when seastars were present, this decrease was marginally nonsignificantly stronger for fed snails than hungry snails (3.8 and 2.7 fold decreases in time spent grazing, respectively; seastar treatment: $F_{1,198}=71.39, \mathrm{p}<0.001$; seastar $\times$ hunger: $F_{1,198}=3.44, \mathrm{p}=0.065 ;$ Fig 5e). While both snail types mediated positive TMIIs, fed snails mediated a marginally nonsignificantly stronger TMII than hungry snails, with 2.9 and 1.6 fold less algae grazed when seastars were present for fed and hungry snails, respectively (seastar treatment: $F_{1,219}=33.93, \mathrm{p}<0.001$; seastar $x$ hunger: $F_{2,219}=2.36, \mathrm{p}=0.097$; Fig. $5 f$ ). Overall, hungry snails ate more algae than fed snails, and algae were not grazed when snails were absent (hunger: $F_{2,219}=$ 90.70, p < 0.001; Fig. 5f).

\section{Waterborne cues}

Waterborne cues from $P$. ochraceus in still water induced $T$. funebralis to graze 2.6 times less microalgae (Poisson Wald $\left.\chi^{2}{ }_{16}=11.84, \mathrm{p}<0.001\right)$ and resulted in 30.6 times more snails leaving the water (Poisson Wald $\chi^{2}{ }_{16}=81.47, \mathrm{p}<0.001$; Fig. 6). In flowing water, dissolved chemical cues from $P$. ochraceus reduced microalgae grazed by snails by 9.4 times at 0 to 15 $\mathrm{cm}$, and 5.5 times at 60 to $75 \mathrm{~cm}$ away (Fig. 7), but did not significantly reduce grazing ( 1.1 fold decrease) at 120 to $135 \mathrm{~cm}$ away (distance treatment: $F_{3,27.58}=$ 

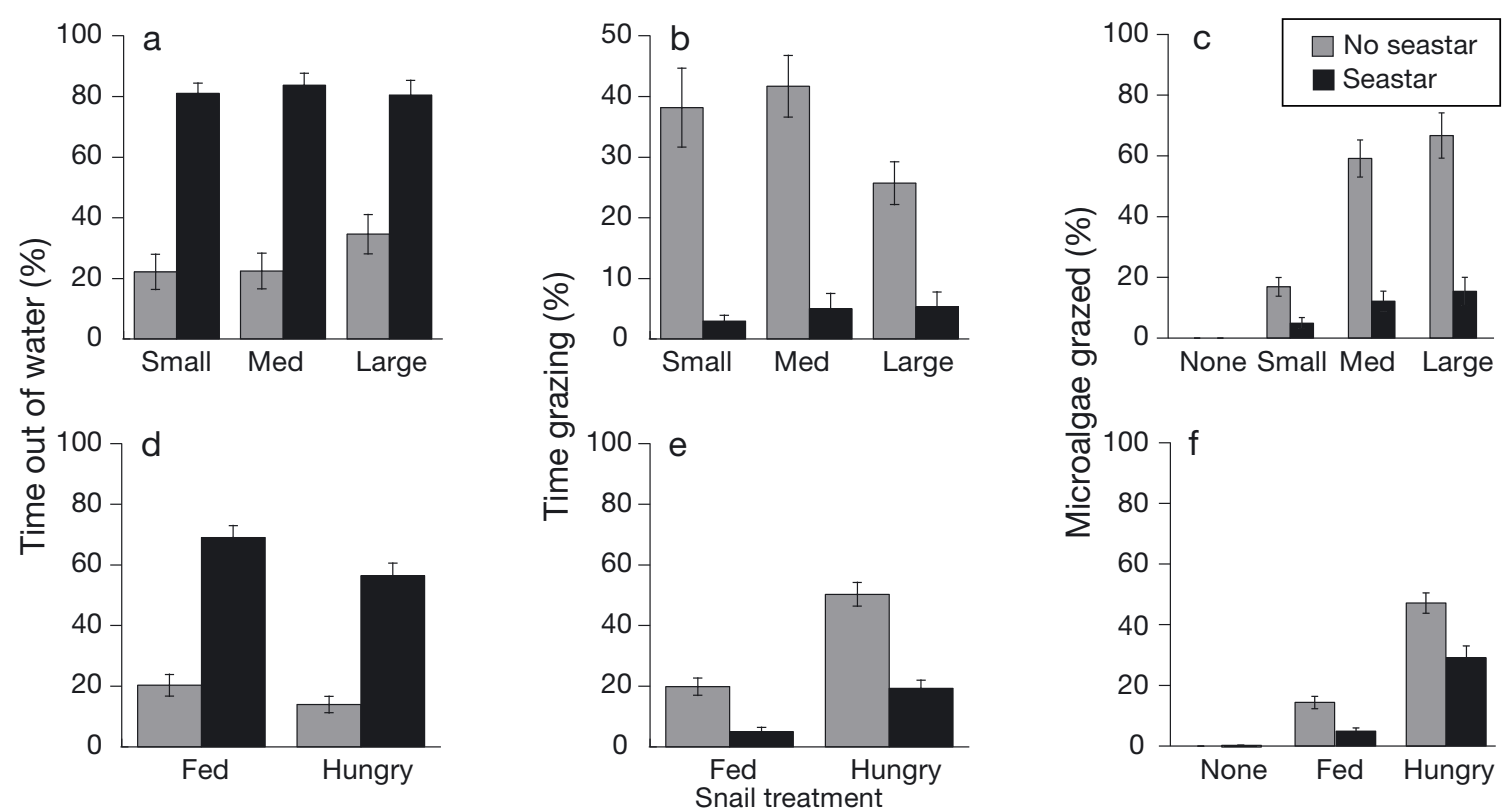

Fig. 5. Size and hunger of Tegula funebralis in the laboratory: mean ( \pm SE) percentage of time that individual snails spent out of water (left) or grazing (middle), and mean ( \pm SE) microalgae grazed (right) after 60 min in laboratory tanks with and without individual Leptasterias spp. present. Top panels (a-c) compare snails of different sizes (small: $<12$ mm; medium: 12-18 mm; large: $>18 \mathrm{~mm}$ shell diameter). Note the different $y$-axis scale in (b). Bottom panels (d-f) compare snails that were either fed or starved for $1 \mathrm{wk}$ in the laboratory before experiments. Replication for size experiments: 26 mesocosms with and without seastars and 9 mesocosms for the 2 controls without snails (none). Replication for hunger experiments: 52 mesocosms with seastars, 51 mesocosms without seastars and 12 mesocosms each for the controls without snails

65.2, $\mathrm{p}<0.001$; seastar treatment: $F_{1,27.12}=49.4, \mathrm{p}<$ 0.001 ; seastar $\times$ distance: $F_{3,27.12}=13.3, \mathrm{p}<0.001$ ). Similarly, dissolved chemical cues from $P$. ochraceus reduced $U$. lactuca grazed by snails by about 33 times at 0 to $15 \mathrm{~cm}$, and 16 times at 60 to $75 \mathrm{~cm}$ away, whereas the cues did not significantly reduce grazing at 120 to $135 \mathrm{~cm}$ away (2.9 times less grazed; distance treatment: $F_{3,28.29}=4.3, \mathrm{p}=0.012$; seastar treatment:
$F_{1,26.96}=19.1, \mathrm{p}<0.001 ;$ seastar $\times$ distance: $F_{3,26.97}=$ 2.9, $\mathrm{p}=0.053$ ) after $16 \mathrm{~h}$ (Fig. 7). Thus, the cues from the seastar reduced grazing on both microalgae and U. lactuca at 0 to 15 and 60 to $75 \mathrm{~cm}$ from the seastar, but not significantly at 120 to $135 \mathrm{~cm}$ away. Random effects of replicate trials accounted for $4.47 \%$ of the variation in trials with microalgae and $15.41 \%$ of the variation in trials with $U$. lactuca.

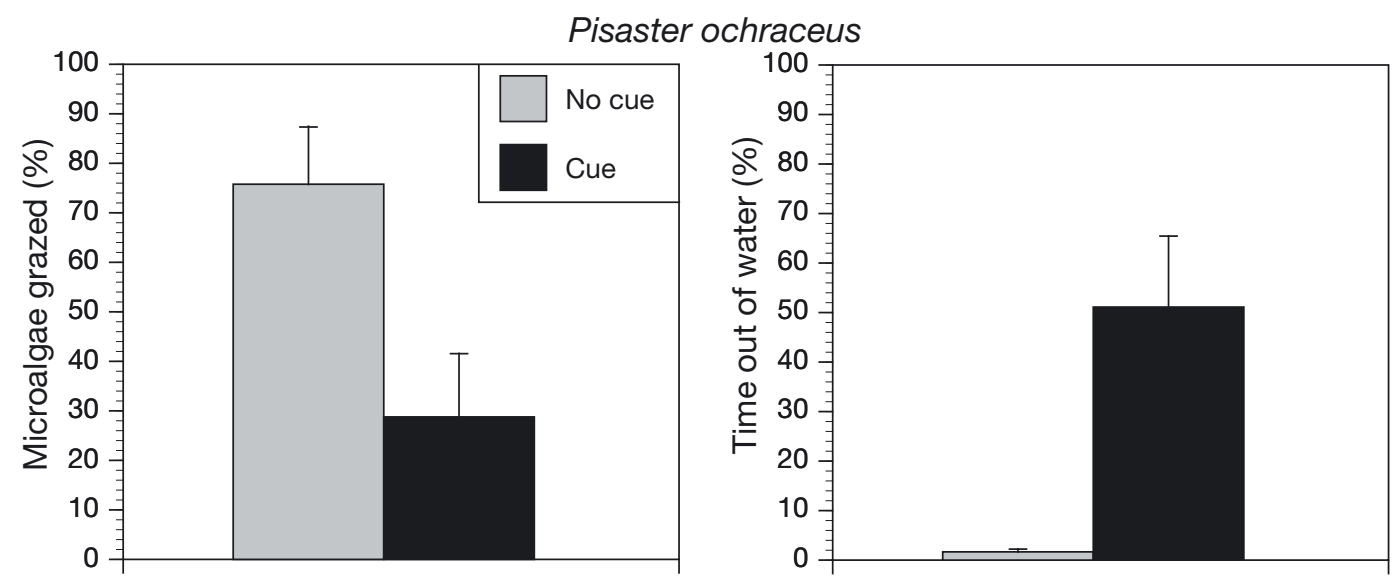

Fig. 6. Waterborne cues from adult Pisaster ochraceus in the laboratory. Mean $( \pm 1 \mathrm{SE})$ proportion of microalgae grazed (left) and time spent out of the water (right) by Tegula funebralis in the presence and absence of dissolved chemical cues from $P$. ochraceus after $1 \mathrm{~h}$ in the laboratory ( $\mathrm{n}=9$ mesocosms) 

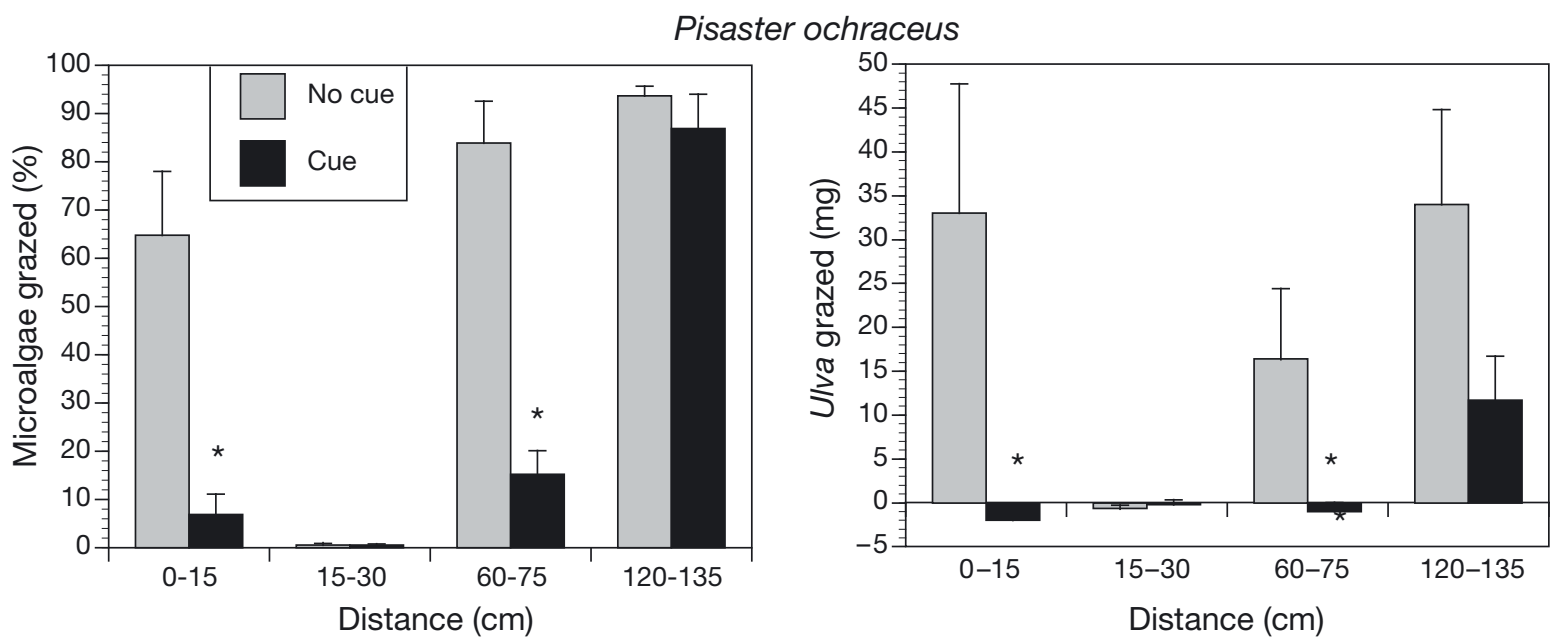

Fig. 7. Waterborne cues from adult Pisaster ochraceus in flow in the laboratory. Mean ( $\pm 1 \mathrm{SE})$ change in microalgae (left) and Ulva lactuca (right) in flow $\left(7.6 \mathrm{~cm} \mathrm{~s}^{-1}\right)$ by 5 Tegula funebralis in the presence $(\mathrm{n}=8)$ and absence $(\mathrm{n}=6)$ of dissolved chemical cues from $P$. ochraceus that were 0-15, 60-75 and 120-135 cm from the seastar after $16 \mathrm{~h}$ in the laboratory. Snails were not placed at the 15 to $30 \mathrm{~cm}$ distance, to serve as a control (see 'Materials and methods: TMII laboratory experiments: Waterborne cues' for details). Significant differences $(\mathrm{p}<0.05)$ between treatments at each distance are indicated by an asterisk

\section{TMII field experiments}

Some T. funebralis typically began climbing walls of tidepools within minutes of adding seastars to tide- pools and evaded seastars by leaving the water. On average, more snails occurred out of water in the presence of both Leptasterias spp. (3.3 times more; $\left.t_{38}=11.24, \mathrm{p}=0.002\right)$ and adult $P$. ochraceus (7.4 times
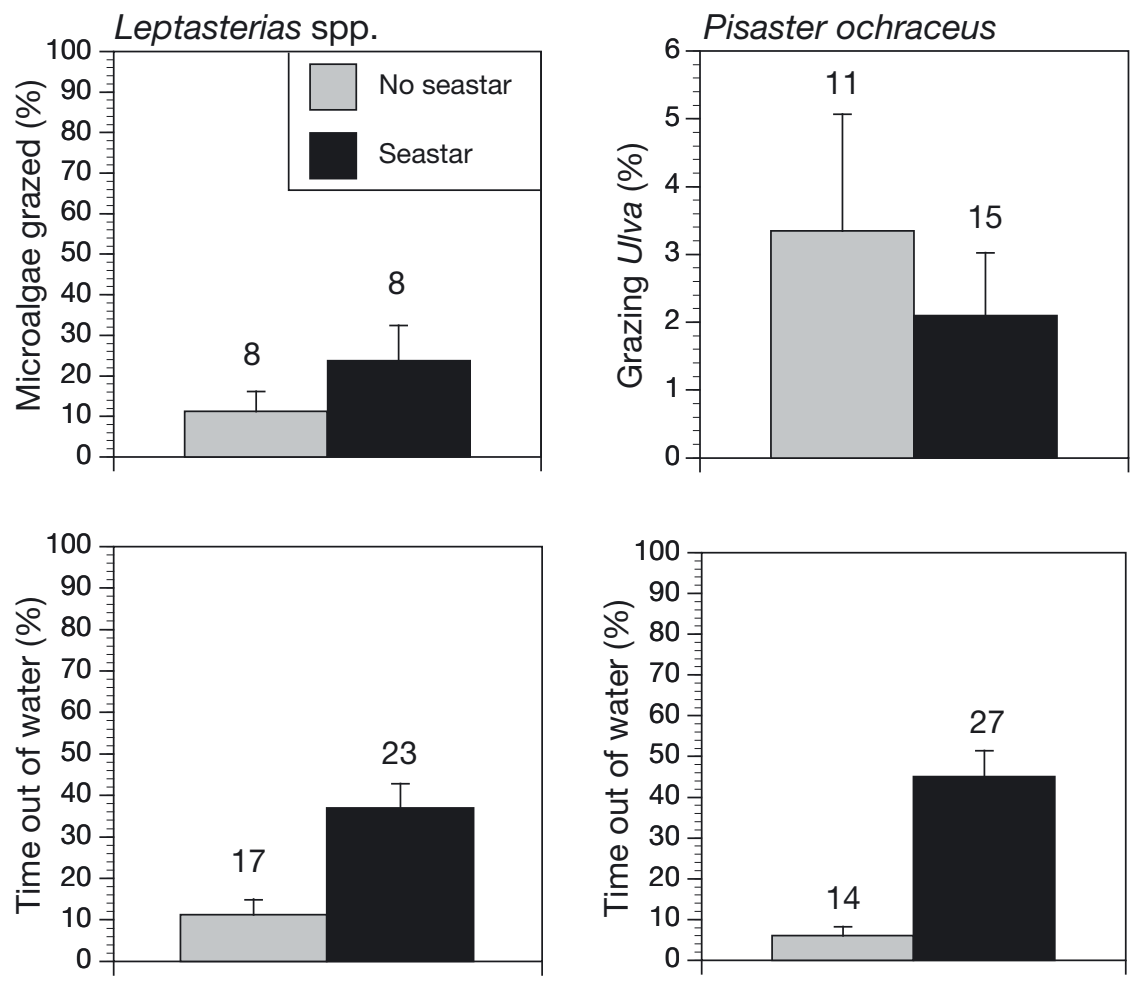

Fig. 8. Adult Pisaster ochraceus and Leptasterias spp. in the field. Mean $( \pm 1 \mathrm{SE})$ proportion of microalgae grazed by Tegula funebralis (top left) or the percentage of snails grazing Ulva lactuca placed in tidepools (top right), and the mean ( $\pm 1 \mathrm{SE}$ ) number of $T$. funebralis out of the water (bottom) after Leptasterias spp. ( $\mathrm{p}=0.0017$, left) and P. ochraceus ( $\mathrm{p}<0.001$, right) were added or not added to tidepools at Horseshoe Cove, northern California. Number of replicate tidepools are shown 
more; $t_{39}=18.28, \mathrm{p}<0.001$; Fig. 8). However, the proportion of microalgae grazed did not differ in the presence and absence of Leptasterias spp. $\left(t_{14}=1.81\right.$, $\mathrm{p}=0.200$ ), and neither did the proportion of snails grazing $U$. lactuca in the presence and absence of adult $P$. ochraceus $\left(t_{24}=0.47, \mathrm{p}=0.499 ;\right.$ Fig. 8$)$.

\section{DISCUSSION}

\section{TMII}

TMII clearly occurred in the laboratory. Adult and juvenile Pisaster ochraceus and Leptasterias spp. seastars all caused Tegula funebralis snails to flee the water and graze less, thereby benefitting microalgae and macroalgae. However, we documented considerable variation in the responses of snails to both species of seastars, which diminished the strength of TMII in the laboratory. A strong dichotomy in fleeing the water was evident in the presence of both seastar species, in which most individuals spent nearly all of their time out of water while others never left the water. By contrast, snails typically spent most of the time in the water when these seastars were absent. Thus, snails did not generally spend their time in air unless evading seastars, presumably due to physiological stress from limited oxygen exchange, higher air temperature and desiccation. However, when seastars were present, some snails apparently risked predation in lieu of exposing themselves to these stressful conditions. Another dichotomy occurred for the amount of algae grazed. When seastars were absent, grazing was highly variable, perhaps because some snails were hungrier than others. However when seastars were present, snails grazed very little even when they remained in the water, presumably due to the imminent threat of predation. Variation in prey traits, such as hunger, size and temperament, are well known to lead prey to exhibit very different antipredator responses, especially when food is present (Werner \& Anholt 1993, Clark 1994, DeWitt et al. 1999, Sih et al. 2004). Additional experiments are needed to demonstrate that the observed dichotomies in the responses of $T$. funebralis to seastars differ consistently among individuals as functions of one or more prey state variables.

Size did not appear to strongly affect the collective responses of snails to seastars in initial or follow-up experiments. In the follow-up experiments with Leptasterias spp., size did not significantly affect the time out of water or time spent grazing in the presence of seastars. The similar flight and grazing responses to
Leptasterias spp. among size classes of snails was unexpected given that only small $T$. funebralis are vulnerable to Leptasterias spp. and only small vulnerable individuals of the sea urchin Strongylocentrotus franciscanus flee the predatory seastar Pycnopodia helianthoides (Freeman 2006). This seemingly suboptimal behavior might be due to the inability of snails to distinguish Leptasterias spp. from larger $P$. ochraceus, which can consume all sizes of snails as they grow. Alternatively, snails surviving attacks by Leptasterias spp. might not learn that the risk of predation abates as they grow (Yarnall 1964). A third explanation for the similar response of all sizes of snails is that seastars starved for $24 \mathrm{~h}$ might not have emitted strong threat cues because recent ingestion of hetero- or conspecifics can increase perception of risk cues by prey, causing stronger avoidance of predators (Jacobsen \& Stabell 2004, Smee \& Weissburg 2006, Weissburg \& Beauvais 2015). This did not appear to be the case in our experiments. All snails responded to Leptasterias spp., regardless of size. Moreover, we did not observe size-dependent differences in responses by snails to juvenile $P$. ochraceus, but large $T$. funebralis were previously shown to be more responsive than small ones to $P$. ochraceus cues (Doering \& Phillips 1983), perhaps because adult $P$. ochraceus prefer large $T$. funebralis (Markowitz 1980).

Though hungry snails spent more time in the water grazing, and grazed more algae than fed snails overall, they were only marginally less responsive to Leptasterias spp. than fed snails, and TMII strength was not significantly weaker when snails were hungry. This was surprising because lower energetic reserves consistently increase risky foraging behavior and weaken TMIIs in many organisms (Werner \& Anholt 1993, Clark 1994, Lima 1998b, Heithaus et al. 2007, Matassa \& Trussell 2014). Though we did not detect a strong effect of size and hunger of $T$. funebralis on fleeing and TMII in response to Leptasterias spp. in the laboratory, we did detect them in companion studies in the field. In tidepools, small $T$. funebralis mediated weak TMIIs, medium snails mediated strong positive TMIIs and large snails (surprisingly) mediated negative TMII in response to Leptasterias spp. (Gravem \& Morgan 2016). Furthermore, small snails responded to mass mortality of Leptasterias spp. by moving into tidepools and lower in the intertidal zone where seastars are more prevalent, whereas large snails did not (Gravem 2015). In addition, we previously found that hungry $T$. funebralis in rocky tidepools continued to forage in the presence of seastars, whereas many fed snails began fleeing imme- 
diately after seastars were placed in tidepools (Gravem \& Morgan 2016). Consequently, TMIIs did not occur in tidepools when snails were hungry, but they did occur when snails were fed. We likely did not detect a stronger effect of the size or hunger of snails on fleeing and TMII in the laboratory due to the close confines of predator and prey in the mesocosms. Snails and seastars often touched in mesocosms, evoking strong flight responses, whereas they did not in tidepools (Gravem \& Morgan 2016). Thus, TMII experiments in the laboratory likely overestimated the flight responses and TMII operating in nature, as with TMII experiments conducted in mesocosms in other systems (Okuyama \& Bolker 2007, Long \& Hay 2012).

Individual variation in boldness and habitat preferences of snails might also be responsible for the individual variation in snail behavior, which may weaken TMII. Individual $T$. funebralis exhibit consistent behavioral syndromes and vary in their responsiveness to $P$. ochraceus, with some individuals being consistently bolder than others (Pruitt et al. 2012). In addition, individual $T$. funebralis possess genetically based habitat preferences, including occurring inside or outside of tidepools and at specific shore levels (Byers \& Mitton 1981, Byers 1983), which would affect their propensity to leave the water in response to predatory seastars. These innate differences in snail temperament may have contributed to the high individual variation that we observed in our experiments.

\section{Waterborne cues}

Behavioral observations during our laboratory experiments in mesocosms revealed that snails contacted by either seastar species immediately turned around and fled in the opposite direction, outpacing the seastars. Even when contact did not occur, snails evaded capture by fleeing the water, indicating that they might have been responding to waterborne chemical cues from seastars. Our subsequent experiments, using caged seastars, dissolved chemical cues of seastars in still water and seastars upstream of snails, confirmed that snails respond to waterborne cues of both seastars without physical contact between predator and prey in this system, as has previously been demonstrated (Feder 1963, Yarnall 1964, Phillips 1976). T. funebralis has long been known to have chemoreceptor organs at the base of the respiratory gills that can detect dissolved chemical cues from predators (Burke 1964, Szal 1971, Croll 1983).
We demonstrated that TMIIs occur in flowing water in the laboratory, raising the possibility that waterborne chemical cues from seastars might also initiate TMIIs in the field. In the laboratory, $T$. funebralis responded to waterborne cues from $P$. ochraceus by reducing grazing on both micro- and macroalgae in low laminar flow $\left(0.51 \mathrm{~min}^{-1}\right)$ when the seastar was as far away as $75 \mathrm{~cm}$ upstream. Furthermore, we observed T. funebralis detect Leptasterias spp. $1 \mathrm{~m}$ away in tidepools; there was however variation among tidepools, probably due to differences in water circulation. Species in other systems have detected chemical cues at similar flow rates and distances (Turner \& Montgomery 2003, Smee et al. 2008, Weissburg et al. 2014, Weissburg \& Beauvais 2015), and antipredator behaviors have also been observed for other prey species near predators in higher flow conditions (Trussell et al. 2004, Freeman 2006, Large et al. 2011). The ability of $T$. funebralis to detect waterborne cues from predatory seastars remains to be determined on waveswept rocky shores at high tide; indeed, their behaviors at high tide are unknown.

T. funebralis responded similarly to Leptasterias spp., and juvenile and adult $P$. ochraceus in both the field and laboratory; the proportion of snails fleeing from seastars was consistently high regardless of species. This was surprising because larger adult $P$. ochraceus pose a greater threat to most snails than do smaller Leptasterias spp., and Leptasterias spp. are more efficient predators of mobile prey than are juvenile $P$. ochraceus of comparable size (Menge 1972). T. funebralis was previously shown to respond more strongly to adult $P$. ochraceus than Leptasterias spp. (Yarnall 1964), perhaps because they were reacting to the higher concentration of cues from much larger adult $P$. ochraceus. By contrast, we previously found that $T$. funebralis might respond more strongly to Leptasterias spp. in the field because small snails moved lower on the shore and into tidepools after the localized mass mortality of Leptasterias spp. despite the continued presence of $P$. ochraceus (Gravem 2015). Molecular identification of the specific cues emitted by the 2 seastars and experiments that determine functional responses of snails to predator biomass, density and cue concentration would be required to determine whether $T$. funebralis can distinguish between these predators.

\section{Tidepools}

Both adult $P$. ochraceus (this study) and Leptasterias spp. (Gravem 2015, Gravem \& Morgan 2016) 
caused snails to flee tidepools in the field, suggesting the potential exists for TMII to occur in nature. Though we did not explore DMII, not one of the hundreds of $T$. funebralis was eaten by either seastar species during laboratory and field trials, and T. funebralis is only one of many different prey items in the diets of $P$. ochraceus and Leptasterias spp. in the field (Feder 1959, Menge 1972, Bartl 1980, Gravem \& Morgan 2016). Furthermore, ours and other studies indicate that this system potentially meets the requirements for strong TMII (He et al. 1993, Peacor \& Werner 2001, Gravem 2015), including (1) rapid responses of prey to predators, (2) many more prey responding to than being eaten by predators and (3) long-term behavioral effects. In our experiments, many dozens of snails rapidly fled from tidepools for physiologically stressful hot, dry halos where grazing might be reduced until high tide, similar to other studies in this system (Yarnall 1964, Gravem 2015) and to studies demonstrating strong effects of predators on habitat use or grazing by other gastropods (Bernot \& Turner 2001, Trussell et al. 2002, 2004, Matassa \& Trussell 2011, Wada et al. 2013). Though our studies were brief, and halos are only a temporary refuge at low tide, $T$. funebralis might leave tidepools for longer than at low tide, thereby extending the duration of the TMII on algae inside tidepools. Indeed, long-term manipulations of Leptasterias spp. and T. funebralis demonstrated that Leptasterias spp. caused $T$. funebralis to continually use halo refuges over 10 mo and caused positive TMIIs on microalgae over 1 mo and macroalgae over 8 mo (Gravem 2015). Others have also demonstrated strong long-term effects of seastars on $T$. funebralis distributions: (1) adding $P$. ochraceus to the lower intertidal zone caused snails to flee to the upper intertidal zone (Markowitz 1980); (2) sites with high predator diversity in the lower intertidal zone $(P$. ochraceus, crabs and octopi) apparently caused snails to shift to the upper intertidal zone (Fawcett 1984); and (3) localized mortality of Leptasterias spp. enabled snails to shift lower in the intertidal zone and tidepools previously occupied by the seastar (Gravem 2015). Though these patterns indicate strong potential for TMIIs to occur in the field, more extensive and longterm field experiments are needed to determine the strength of TMIIs and DMIIs mediated by seastars in these tidepool communities.

Even though snails evaded predatory seastars by fleeing the tidepools, we did not detect significant reductions in grazing in the presence of seastars during field trials. TMIIs might have been masked by omnivorous hermit crabs which were abundant, readily grazed microalgae and did not appear to alter their behavior in response to seastars. TMII on U. lactuca might not have been detected because the $1 \mathrm{~h}$ trials might not have been long enough; snails often scraped the surface of the blade without diminishing it.

If seastars indeed initiate TMIIs in the field, our palatability studies indicate that the strongest benefits might be conferred on tidepool microalgae and several species of macroalgae that were preferred by T. funebralis. These macroalgae included the relatively fast-growing U. lactuca, Cladophora columbiana and Porphyra spp. over the other 4 species of algae, which might be slower-growing and chemically or structurally defended (Watanabe 1984, Steinberg 1985). Similar feeding preferences were found in a recent laboratory study, despite minor differences in the rankings of algae (Aquilino et al. 2012).

\section{CONCLUSIONS}

Our small mesocosms and short experiments do not reflect the strength of TMIIs for natural populations at longer time scales, as with other TMII experiments conducted in mesocosms in other systems (Okuyama \& Bolker 2007, Long \& Hay 2012). However, our suite of experiments do indicate the potential for TMIIs to occur in tidepools, setting the stage for more challenging field tests to distinguish the interaction strength and persistence of both TMIIs and DMIIs across the landscape (Huang \& Sih 1990, Schmitz 2004, Prasad \& Snyder 2006, Mooney \& Agrawal 2008, Laundré et al. 2010). Moreover, our results emphasize the need to incorporate behavior into studies, to provide comprehensive estimations of the cascading impacts of predation on communities (Peacor \& Werner 2001, Schmitz et al. 2003, Preisser et al. 2005, Ohgushi et al. 2012). Finally, by conducting many replicate feeding and behavioral trials in the laboratory, we gained interesting insights regarding individual variation in predator-prey responses that warrant further attention. Our study adds to the growing body of empirical evidence supporting model predictions that individual variation in prey state alters TMII strength (Ovadia \& Schmitz 2002, Luttbeg et al. 2003, Persson \& De Roos 2003, Kotler et al. 2004, Freeman 2006, Rudolf 2012, Matassa \& Trussell 2014, Gravem \& Morgan 2016).

Acknowledgements. We thank the many undergraduate and graduate students who participated in conducting this research over the years. Student support was provided by the National Science Foundation Research Experience for 
Undergraduates program (DBI-0753226) awarded to S. L. Williams and E. D. Sanford, National Science Foundation GK-12 (0841297) awarded to S. L. Williams, Mildred E. Mathias Foundation, Henry A. Jastro Fellowship, UC Davis Graduate Group in Ecology, and Bodega Marine Laboratory. This is a contribution of Bodega Marine Laboratory.

\section{LITERATURE CITED}

Abrams PA (1995) Implications of dynamically variable traits for identifying, classifying and measuring direct and indirect effects in ecological communities. Am Nat 146: 112-134

> Abrams PA (2007) Defining and measuring the impact of dynamic traits on interspecific interactions. Ecology 88: 2555-2562

Appleton RD, Palmer AR (1988) Water-borne stimuli released by predatory crabs and damaged prey induce more predator-resistant shells in a marine gastropod. Proc Natl Acad Sci USA 85:4387-4391

> Aquilino KM, Coulbourne ME, Stachowicz JJ (2012) Mixed species diets enhance the growth of two rocky intertidal herbivores. Mar Ecol Prog Ser 468:179-189

Aschaffenburg MD (2008) Different crab species influence feeding of the snail Nucella lapillus through traitmediated indirect interactions. Mar Ecol 29:348-353

Bartl S (1980) A comparison of the feeding behavior of the six-rayed seastar, Leptasterias hexactis, and from two intertidal habitats. BML student report. Bodega Marine Laboratory Cadet Hand Library, University of California Davis, Bodega Bay, CA

> Behrens Yamada S, Navarrete SA, Needham C (1998) Predation induced changes in behavior and growth rate in three populations of the intertidal snail, Littorina sitkana (Philippi). J Exp Mar Biol Ecol 220:213-226

> Bernot RJ, Turner AM (2001) Predator identity and traitmediated indirect effects in a littoral food web. Oecologia 129:139-146

Burke WR (1964) Chemoreception by Tegula funebralis. Veliger 6:17-20

Byers BA (1983) Enzyme polymorphism associated with habitat choice in the intertidal snail Tegula funebralis. Behav Genet 13:65-75

Byers B, Mitton J (1981) Habitat choice in the intertidal snail Tegula funebralis. Mar Biol 65:149-154

Carlton JT (ed) (2007) The Light and Smith manual: intertidal invertebrates from central California to Oregon, 4th edn. University of California Press, Berkeley, CA

> Clark CW (1994) Antipredator behavior and the assetprotection principle. Behav Ecol 5:159-170

Croll RP (1983) Gastropod chemoreception. Biol Rev Camb Philos Soc 58:293-319

DeWitt TJ, Sih A, Hucko JA (1999) Trait compensation and cospecialization in a freshwater snail: size, shape and antipredator behaviour. Anim Behav 58:397-407

Dill LM, Heithaus MR, Walters CJ (2003) Behaviorally mediated indirect interactions in marine communities and their conservation implications. Ecology 84:1151-1157

> Doering PH, Phillips DW (1983) Maintenance of the shorelevel size gradient in the marine snail Tegula funebralis (A. Adams): importance of behavioral responses to light and sea star predators. J Exp Mar Biol Ecol 67:159-173

Fawcett MH (1984) Local and latitudinal variation in predation on an herbivorous marine snail. Ecology 65:
$1214-1230$

Feder HM (1959) The food of the starfish, Pisaster ochraceus along the California coast. Ecology 40:721-724

Feder HM (1963) Gastropod defensive responses and their effectiveness in reducing predation by starfishes. Ecology 44:505-512

Flowers JM, Foltz DW (2001) Reconciling molecular systematics and traditional taxonomy in a species-rich clade of sea stars (Leptasterias subgenus Hexasterias). Mar Biol 139:475-483

Freeman A (2006) Size-dependent trait-mediated indirect interactions among sea urchin herbivores. Behav Ecol 17: 182-187

Gravem SA (2015) Linking antipredator behavior of prey to intertidal zonation and community structure in rocky tidepools. PhD thesis, University of California, Davis, CA

> Gravem SA, Morgan SG (2016) Prey state alters traitmediated indirect interactions in rocky tide pools. Funct Ecol, doi:10.1111/1365-2435.12628

> Hairston NG, Smith FE, Slobodkin LB (1960) Community structure, population control and competition. Am Nat 94:421-425

He X, Wright R, Kitchell JF (1993) Fish behavioral and community responses to manipulation. In: Carpenter $\mathrm{S}$, Kitchell J (eds) The trophic cascade in lakes. Cambridge University Press, Cambridge, p 69-84

> Heithaus MR, Frid A, Wirsing AJ, Dill LM and others (2007) State-dependent risk-taking by green sea turtles mediates top-down effects of tiger shark intimidation in a marine ecosystem. J Anim Ecol 76:837-844

Huang CF, Sih A (1990) Experimental studies on behaviorally mediated, indirect interactions through a shared predator. Ecology 71:1515-1522

Jacobsen HP, Stabell OB (2004) Antipredator behaviour mediated by chemical cues: the role of conspecific alarm signalling and predator labelling in the avoidance response of a marine gastropod. Oikos 104:43-50

Kotler BP, Brown JS, Bouskila A (2004) Apprehension and time allocation in gerbils: the effects of predatory risk and energetic state. Ecology 85:917-922

Large SI, Smee DL, Trussell GC (2011) Environmental conditions influence the frequency of prey responses to predation risk. Mar Ecol Prog Ser 422:41-49

Laundré JW, Hernandez L, Ripple WJ (2010) The landscape of fear: ecological implications of being afraid. Open Ecol J 3:1-7

Lima SL (1998a) Nonlethal effects in the ecology of predator-prey interactions: What are the ecological effects of anti-predator decision-making? Bioscience 48:25-34

Lima SL (1998b) Stress and decision making under the risk of predation: recent developments from behavioral, reproductive, and ecological perspectives. Adv Stud Behav 27:215-290

Long JD, Hay ME (2012) The impact of trait-mediated indirect interactions in marine communities. In: Ohgushi $\mathrm{T}$, Schmitz OJ, Holt RD (eds) Trait-mediated indirect interactions: ecological and evolutionary perspectives. Cambridge University Press, New York, NY, p 47-68

Luttbeg B, Trussell GC (2013) How the informational environment shapes how prey estimate predation risk and the resulting indirect effects of predators. Am Nat 181: 182-194

> Luttbeg B, Rowe L, Mangel M (2003) Prey state and experimental design affect relative size of trait- and densitymediated indirect effects. Ecology 84:1140-1150 
Markowitz DV (1980) Predator influence on shore-level size gradients in Tegula funebralis (A. Adams). J Exp Mar Biol Ecol 45:1-13

Matassa CM, Trussell GC (2011) Landscape of fear influences the relative importance of consumptive and nonconsumptive predator effects. Ecology 92:2258-2266

Matassa CM, Trussell GC (2014) Prey state shapes the effects of temporal variation in predation risk. Proc R Soc B 281:20141952, doi:10.1098/rspb.2014.1952

Menge BA (1972) Competition for food between two intertidal starfish species and its effect on body size and feeding. Ecology 53:635-644

> Menge JL, Menge BA (1974) Role of resource allocation, aggression and spatial heterogeneity in coexistence of two competing intertidal starfish. Ecol Monogr 44: 189-209

Mooney KA, Agrawal AA (2008) Phenotypic plasticity. In: Tilmon KJ (ed) Specialization, speciation, and radiation: the evolutionary biology of herbivorous insects. University of California Press, Berkeley, CA, p 43-57

Nielsen KJ (2001) Bottom-up and top-down forces in tide pools: test of a food chain model in an intertidal community. Ecol Monogr 71:187-217

Ohgushi T, Schmitz O, Holt RD (2012) Introduction. In: Ohgushi T, Schmitz O, Holt RD (eds) Trait-mediated indirect interactions: ecological and evolutionary perspectives. Cambridge University Press, New York, NY, p $1-6$

Okuyama T, Bolker BM (2007) On quantitative measures of indirect interactions. Ecol Lett 10:264-271

> Ovadia O, Schmitz OJ (2002) Linking individuals with ecosystems: experimentally identifying the relevant organizational scale for predicting trophic abundances. Proc Natl Acad Sci USA 99:12927-12931

Paine RT (1969) The Pisaster-Tegula interaction: prey patches, predator food preference and intertidal community structure. Ecology 50:950-961

> Paine RT (1980) Food webs: linkage, interaction strength and community infrastructure. The third Tansley lecture. J Anim Ecol 49:667-685

> Peacor SD, Werner EE (1997) Trait-mediated indirect interactions in a simple aquatic food web. Ecology 78 : 1146-1156

Peacor SD, Werner EE (2001) The contribution of traitmediated indirect effects to the net effects of a predator. Proc Natl Acad Sci USA 98:3904-3908

> Peckarsky BL, McIntosh AR (1998) Fitness and community consequences of avoiding multiple predators. Oecologia 113:565-576

> Peckarsky BL, Abrams PA, Bolnick DI, Dill LM, and others (2008) Revisiting the classics: considering nonconsumptive effects in textbook examples of predator-prey interactions. Ecology 89:2416-2425

Persson L, De Roos AM (2003) Adaptive habitat use in sizestructured populations: linking individual behavior to population processes. Ecology 84:1129-1139

Phillips DW (1976) Effect of a species-specific avoidance response to predatory starfish on the intertidal distribution of two gastropods. Oecologia 23:83-94

> Prasad RP, Snyder WE (2006) Diverse trait-mediated interactions in a multi-predator, multi-prey community. Ecology 87:1131-1137

Preisser EL, Bolnick DI, Benard MF (2005) Scared to death? The effects of intimidation and consumption in predatorprey interactions. Ecology 86:501-509
Pruitt JN, Stachowicz JJ, Sih A (2012) Behavioral types of predator and prey jointly determine prey survival: potential implications for the maintenance of within-species behavioral variation. Am Nat 179:217-227

> Quinn BK, Boudreau MR, Hamilton DJ (2012) Inter- and intraspecific interactions among green crabs (Carcinus maenas) and whelks (Nucella lapillus) foraging on blue mussels (Mytilus edulis). J Exp Mar Biol Ecol 412: $117-125$

Raimondi PT, Forde SE, Delph LF, Lively CM (2000) Processes structuring communities: evidence for traitmediated indirect effects through induced polymorphisms. Oikos 91:353-361

Rudolf V (2012) Trait-mediated indirect interactions in size-structured populations: causes and consequences for species interactions and community dynamics. In: Ohgushi T, Schmitz O, Holt RD (eds) Trait-mediated indirect interactions: ecological and evolutionary perspectives. Cambridge University Press, New York, NY, p 69-88

Schmitz OJ (1998) Direct and indirect effects of predation and predation risk in old-field interaction webs. Am Nat 151:327-342

Schmitz OJ (2004) Perturbation and abrupt shift in trophic control of biodiversity and productivity. Ecol Lett 7 : 403-409

Schmitz OJ, Adler FR, Agrawal AA (2003) Linking individual-scale trait plasticity to community dynamics. Ecology 84:1081-1082

Selden R, Johnson AS, Ellers O (2009) Waterborne cues from crabs induce thicker skeletons, smaller gonads and sizespecific changes in growth rate in sea urchins. Mar Biol 156:1057-1071

Sih A (1992) Prey uncertainty and the balancing of antipredator and feeding needs. Am Nat 139:1052-1069

Sih A, Bell A, Johnson JC (2004) Behavioral syndromes: an ecological and evolutionary overview. Trends Ecol Evol 19:372-378

Smee DL, Weissburg MJ (2006) Hard clams (Mercenaria mercenaria) evaluate predation risk using chemical signals from predators and injured conspecifics. J Chem Ecol 32:605-615

Smee DL, Ferner MC, Weissburg MJ (2008) Alteration of sensory abilities regulates the spatial scale of nonlethal predator effects. Oecologia 156:399-409

> Smee DL, Ferner MC, Weissburg MJ (2010) Hydrodynamic sensory stressors produce nonlinear predation patterns. Ecology 91:1391-1400

Steinberg PD (1985) Feeding preferences of Tegula funebralis and chemical defenses of marine brown algae. Ecol Monogr 55:333-349

Szal R (1971) 'New' sense organ of primitive gastropods. Nature 229:490-492

Trussell GC, Ewanchuk PJ, Bertness MD (2002) Field evidence of trait-mediated indirect interactions in a rocky intertidal food web. Ecol Lett 5:241-245

Trussell GC, Ewanchuk PJ, Bertness MD, Silliman BR (2004) Trophic cascades in rocky shore tide pools: distinguishing lethal and nonlethal effects. Oecologia 139:427-432

Trussell GC, Ewanchuk PJ, Matassa CM (2006) Habitat effects on the relative importance of trait- and densitymediated indirect interactions. Ecol Lett 9:1245-1252

Turner AM, Montgomery SL (2003) Spatial and temporal scales of predator avoidance: experiments with fish and snails. Ecology 84:616-622 
Wada Y, Iwasaki K, Yusa Y (2013) Changes in algal community structure via density- and trait-mediated indirect interactions in a marine ecosystem. Ecology 94: 2567-2574

Watanabe JM (1984) Food preference, food quality and diets of three herbivorous gastropods (Trochidae: Tegula) in a temperate kelp forest habitat. Oecologia 62:47-52

> Weissburg M, Beauvais J (2015) The smell of success: the amount of prey consumed by predators determines the strength and range of cascading non-consumptive effects. PeerJ 3:e1426

Weissburg MJ, Zimmer-Faust RK (1993) Life and death in moving fluids: hydrodynamic effects on chemosensory-

Editorial responsibility: Lisandro Benedetti-Cecchi, Pisa, Italy mediated predation. Ecology 74:1428-1443

Weissburg MJ, Ferner MC, Pisut DP, Smee DL (2002) Ecological consequences of chemically mediated prey perception. J Chem Ecol 28:1953-1970

Weissburg M, Smee DL, Ferner MC (2014) The sensory ecology of nonconsumptive predator effects. Am Nat 184:141-157

Werner EE, Anholt BR (1993) Ecological consequences of the trade-off between growth and mortality rates mediated by foraging activity. Am Nat 142:242-272

Yarnall JL (1964) The responses of Tegula funebralis to starfishes and predatory snails (Mollusca: Gastropoda). Veliger 6:56-58

Submitted: October 9, 2015; Accepted: May 10, 2016

Proofs received from author(s): June 21, 2016 